\title{
Influence of different regimes of humidification upon humus state of alluvial-meadow soils
}

\author{
Hyzhniak I. \\ NSC «A.N.Sokolovsky Institute of soil science and agrochemistry»
}

The purpose. To determine changes of quantitative and quality indicators of humus of alluvial-meadow heavy clayloam soil at different regimes of its humidification. Methods. Theoretical justification, laboratorymodel experiments, chemical analysis and statistical. Results. It is determined that regime of humidification for the term of composting (9 months) has not influenced the general content of humus. At the same time its group and fractional composition has essential varied. At optimum and contrasting humidification ratio Sgk:Sfk was augmented primarily due to accumulation of humates, and at overwetting, on the contrary, has converged due to fulvatization of humus. Conclusions. Optimum conditions of humidification promoted fixation of humus matters in the form of humates of calcium, and contrasting - to fixation of humus matters by finely dispersed mineral part. Fixed overwetting of soil has led to fulvatization of humus due to accumulation fulvate group.

Key words: alluvial-meadow soils, regimes of humidification, humus state, fractional composition of humus.

Introduction. Floodplain soils belong to intrazonal formations, but they are still genetically associated with automorphic soils of watershed [1-3]. An important additional condition of the genesis of meadow soils in floodplains, according to Rode A.A. [4], there is a hydromorphism - superficial (periodic flooding of the floodplain with flood waters) and subsoil (wetting and gelling of the lower part of the alluvial-meadow soils' profile due to the close occurrence of the underground water). That is, an important factor influencing the nature of the organic matter humification in floodplain soils and the accumulation and composition of humus is the manifestation of special hydrological conditions in a flood landscape [5, 6]. In the paper [7] it is also noted that the major factor influencing morphogenesis and the nature of the functioning of floodplain soils is the intensity of the development of hydromorphic processes in their time and profile measurements.

The purpose of the research is to establish changes in the quantitative and qualitative characteristics of the humus of the alluvial-meadow heavy-soil soil in different modes of its moistening.

Materials and methods of the research. To achieve the goal, a model experiment was carried out. It provided a composting of alluvial-meadow soil for 9 months on the following variants: 1) without moistening (control); 2) optimal moistening (60\% of TMC); 3) contrast moistening (100\% of TMC once every 2 months); 4) permanent waterlogging (100\% of TMC). Glucose was added to each variant to activate microbiological activity. Alluvial-meadow soil was used in the model experiment with the following general characteristics: $\mathrm{pH}_{\text {water }}-7.68$, the content of particles $<0,001 \mathrm{~mm}-32,55 \%,<0,01 \mathrm{~mm}-55,79 \%$, the content of $\mathrm{C}_{\text {org. }}$ $2,34 \%$. Analytical studies were carried out according to the current standardized methods: carbon of organic matter by the method of I.V. Tyurin according to DSTU 4289 [8], group and fractional composition of humus according to Tyurin method in the modification of Ponomareva and Plotnikova in accordance with DSTU 7828 [9]. The parameters of indicators of humus state were estimated using the parameters that were carried out by D.S. Orlov [10]. Statistical processing of the results was performed using Excel.

The results of the research. The results of studies have shown that different modes of humidification of alluvial-meadow soil during the experiment did not significantly affect the content of humus in it (Table 1). However, in the variant with optimal humidification, a slight increase in the content of humus (by $6 \%$ ) is observed, as compared to the control, which is explained by the optimum conditions for passing processes of humus substances formation and fixation within the soil. 
Table 1. Humus content in the alluvial-meadow soil under its various moistening

\begin{tabular}{|c|c|c|}
\hline №№ & Mode of humidification & Humus content, $\%$ \\
\hline 1. & Without moistening & $4,04 \pm 0,24$ \\
\hline 2. & Optimal moistening & $4,26 \pm 0,21$ \\
\hline 3. & Contrast moistening & $4,14 \pm 0,44$ \\
\hline 4. & Permanent waterlogging & $4,15 \pm 0,17$ \\
\hline & SSD $_{05}$ & 0,12 \\
\hline
\end{tabular}

However, the humidification regime significantly influenced the quality of the humus of alluvial-meadow soil (Figure).

Fig. Group composition of the humus of alluvial-meadow soil under different modes of humidification

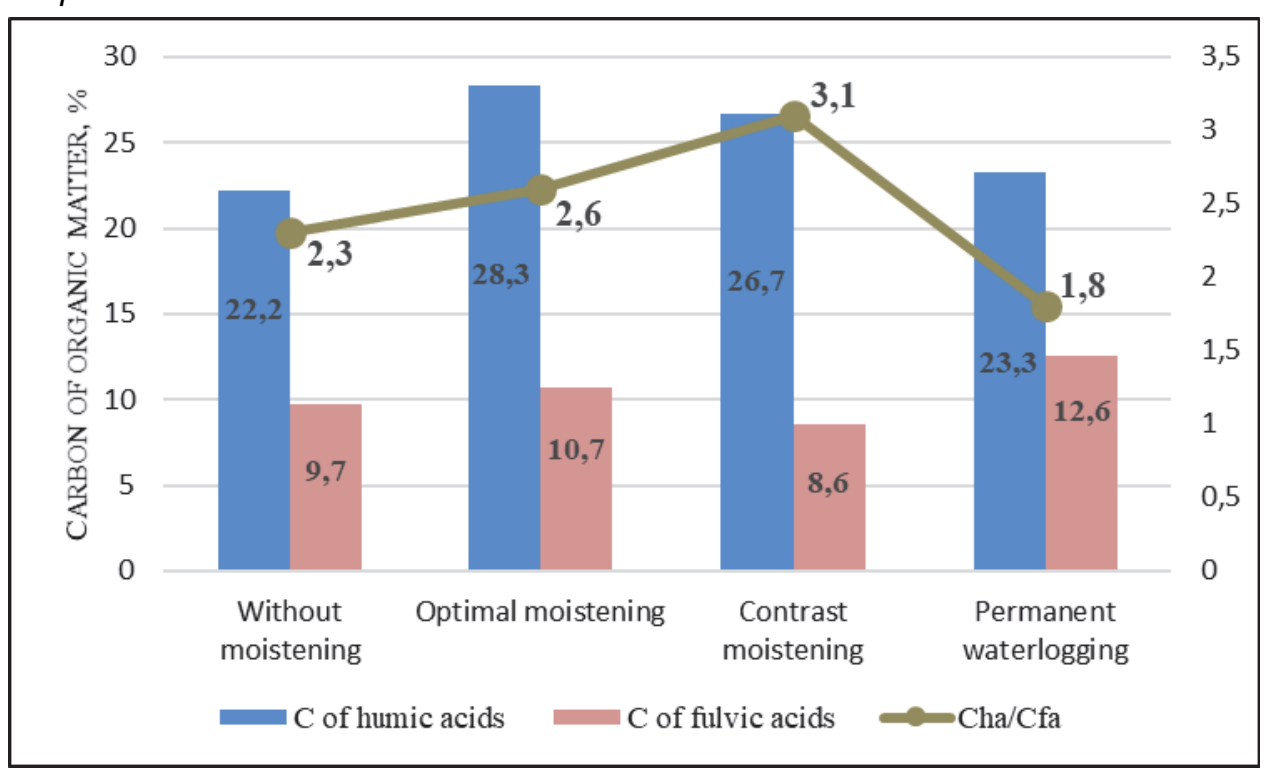

Thus, in the group composition of humus the humate part has increased by $20 \%$ of the $C_{\text {tot. }}$ in the variants of optimum and contrast moisture of the investigated soil, therefore the parameters of the indicator $\mathrm{C}_{\mathrm{ha}}: \mathrm{C}_{\mathrm{fa}}$, which characterizes the type of humus, expanded to 2,6 (purely humate) and 3,1 (purely humate), respectively. However, in the variant with permanent waterlogging, on the contrary, a significant increase (by $30 \%$ of the $C_{\text {tot. }}$ ) of the fulvate part of humus was noted, and the ratio of $C_{\mathrm{ha}}: \mathrm{C}_{\mathrm{fa}}$ narrowed to 1,8 (humate), compared to 2,3 (purely humate) on the control. In our view, such a pattern can be explained by the conversion of relatively stable humic acids into more mobile fulvic acids when waterlogging occurs. The sum of extracted humus substances in all variants of humidification has grown almost in 1,2 times, compared with the mode without moisturizing.

In the fractional composition of the humus of alluvial-meadow soil (Table 2), in the variant with the optimum moistening an increasing of the humic acids fraction, connected with calcium (HA-2), has been observed from $11,5 \%$ on the control to $15,4 \%\left(\mathrm{SSD}_{05}=3,4\right)$.

Table 2. Fractional composition of the humus of alluvial-meadow soil under different modes of humidification

\begin{tabular}{|c|c|c|c|c|c|c|c|c|c|c|}
\hline \multirow{2}{*}{ Mode of humidification } & \multirow{2}{*}{$\% \mathrm{C}_{\text {org. }}$} & \multicolumn{4}{|c|}{ C of humic acids } & \multicolumn{5}{|c|}{ C of fulvic acids } \\
\hline & & 1 & 2 & 3 & sum & $1 \mathrm{a}$ & 1 & 2 & 3 & sum \\
\hline Without moistening & 2,34 & 3,0 & 11,5 & 7,7 & 22,2 & 3,0 & 0,5 & 2,8 & 3,4 & 9,7 \\
\hline Optimal moistening & 2,47 & 4,0 & 15,4 & 8,9 & 28,3 & 2,6 & 0,6 & 4,3 & 3,2 & 10,7 \\
\hline Contrast moistening & 2,40 & 3,8 & 13,7 & 9,2 & 26,7 & 1,8 & 0,9 & 1,6 & 4,3 & 8,6 \\
\hline $\begin{array}{c}\text { Permanent } \\
\text { waterlogging }\end{array}$ & 2,41 & 4,4 & 12,2 & 6,7 & 23,3 & 2,2 & 1,5 & 6,1 & 3,3 & 13,1 \\
\hline $\mathrm{SSD}_{05}$ & 0,07 & 0,9 & 3,4 & 1,3 & 2,7 & 1,1 & 0,9 & 2,2 & 1,5 & 1,4 \\
\hline
\end{tabular}


continuation of Table 2

\begin{tabular}{|c|c|c|c|c|c|}
\hline $\begin{array}{c}\text { Mode of } \\
\text { humidification }\end{array}$ & $\% \mathrm{C}_{\mathrm{org}}$ & $\mathrm{C}_{\mathrm{ha}}+\mathrm{C}_{\mathrm{fa}}$ & $\mathrm{C}_{\mathrm{ha}} / \mathrm{C}_{\mathrm{fa}}$ & Humines & $\mathrm{C} / \mathrm{N}$ \\
\hline Without moistening & 2,34 & 31,9 & 2,3 & 68,1 & 10,2 \\
\hline Optimal moistening & 2,47 & 39,0 & 2,6 & 61,0 & 10,3 \\
\hline Contrast moistening & 2,40 & 35,3 & 3,1 & 64,7 & 10,2 \\
\hline $\begin{array}{c}\text { Permanent } \\
\text { waterlogging }\end{array}$ & 2,41 & 36,4 & 1,8 & 63,6 & 10,3 \\
\hline SSD $_{05}$ & 0,07 & 2,1 & - & 2,1 & - \\
\hline
\end{tabular}

In the humus fractional composition the fraction of humic acids, strongly connected with the mineral part of the soil (GA-3), has increased from $7,7 \%$ in the control variant to $9,2 \%\left(S_{S D_{05}}=1,3\right)$ during the periodic alternation of aerobic and anaerobic conditions of the investigated soil. That is, as a result of a better sorption of humus substances on the surface of mineral particles. In the variant with a permanent waterlogging, as has been expected, there was an increasing in the fulvic part of humus, mainly due to the fraction of fulvic acids, connected with calcium (FA-2) and due to the fraction of mobile fulvic acids (FA-1). It is also worth noting that in all variants of moistening the mobility of the most aggressive fraction of fulvic acids (FA-1a) has decreased.

The level of supply of humus by nitrogen in the control variant was average, as shown by the $\mathrm{C} / \mathrm{N}$ index of 10,2 , and the humidity regimes during the research period did not significantly affect its change. The degree of organic matter humification in all variants was too high (65-76 \%).

\section{Conclusions}

Thus, different hydrological regimes, which are stored on the floodplain during the year, influence the transformation of organic matter in alluvial-meadow soils, mainly causing a change in the quantitative characteristic of humus. Optimal conditions of moisture have helped to fix humus substances in the form of calcium humates, and contrast - to fix humus substances with fine mineral part. Permanent waterlogging of soil caused the humus to be fulvatizated by the accumulation of a fulvic acids group.

\section{Bibliography}

1. Dobrovolsky G.V. (2005). The floodplain soils of the Center of the Russian plain. [2nd est., adapt. and add.]. Moskva: Publ.house of the Moscow State University. 293 p. [In Russian].

2. Tikhonenko D.G., Gorin M.O., Yazikova A.G. and others. (2002). Methodology of the search for land use strategies in the study of pedogenesis and soil cultivation of valley landscapes. Agrochemistry and soil science. B. 1. Kharkiv. P. 40-53. [In Ukrainian].

3. Grassland - a European Resource: 24-th General Meeting of the European Grassland Federation (Lublin, Poland 3-7 June 2012) / Poznan, 2012. - Vol.17. - 805 p.

4. Rode A.A. Soil Genesis and Modern Soil Formation Processes. Moscow: Nauka, 1984. 255 p. [In Russian].

5. Samoylova E.M., Yakovchenko V.P. (1988). Humification of plant residues and humus fixation under different humidification regimes. Bulletin of the Moscow University. No. 3. P. 8-13. [In Russian].

6. Akhtyrtsev B.P., Akhtyrtsev A.B., Yablonsky L.A. (2004). The humus state transformation of foreststeppe soils under the influence of hydromorphism. Vestnik VSU. No. 2. P. 99-107. [In Russian].

7. Truskavetsky R. (2008). Morphogenetic features and use of floodplain soils of the Left-bank Foreststeppe zone of Ukraine. Genesis, geography and soil ecology. Collection of scientific works. 616 p. [In Ukrainian].

8. The quality of the soil. Methods for determination of organic matter: DSTU 4289: 2004. [Effective from 2005-07-01]. Kyiv: Derzhspozhyvstandart of Ukraine, 2005. 14 p. (National Standard of Ukraine). [In Ukrainian]. 
9. The quality of the soil. Determination of the group and fractional composition of humus using the Tyurin method in the modification of Ponomareva and Plotnikova: DSTU 7828: 2015. [Effective from 01-07-2016]. K.: DP "UkrNDNTS", 2016. 14 p. (National Standard of Ukraine). [In Ukrainian].

10. Orlov D.S., Biryukova O.N., Rozanova M.S. (2004). Additional indicators of the humus state of soils and their genetic horizons. Soil science. No. 8. P. 38-45. [In Russian]. 